This is a self-archived version of an original article. This version may differ from the original in pagination and typographic details.

Author(s): Ihalainen, Pasi; Saarinen, Taina

Title: Integrating a Nexus : the History of Political Discourse and Language Policy Research

Year: 2019

Version: Accepted version (Final draft)

Copyright: (C) 2019 Informa UK Limited, trading as Taylor \& Francis Group

Rights: In Copyright

Rights url: http://rightsstatements.org/page//nC/1.0/?language=en

Please cite the original version:

Ihalainen, P., \& Saarinen, T. (2019). Integrating a Nexus : the History of Political Discourse and Language Policy Research. Rethinking History, 23(4), 500-519.

https://doi.org/10.1080/13642529.2019.1638587 
Integrating a nexus: Language Policy Research and the History of Political Discourse

Pasi Ihalainen $^{a *}$ and Taina Saarinen ${ }^{b}$

${ }^{a}$ Department of History and Ethnology, University of Jyväskylä, Jyväskylä, Finland; ${ }^{b}$ Centre for Applied Language Studies, University of Jyväskylä, Jyväskylä, Finland

*corresponding author: Department of History and Ethnology, P.O.B. 35 (H), 40014 University of Jyväskylä, Finland, pasi.t.ihalainen@jyu.fi, ORCiD 0000-0002-54684829 


\section{Integrating a nexus: Language Policy Research and the History of Political Discourse}

Abstract

Historians of political discourse and language policy researchers should join forces to develop methods of textual analysis that help to integrate political and intellectual history. They could do so by focusing their analysis on interconnections between material realities, human physical action, practices and structures, as well as institutions and ideologies as discursive constructs. Such a version of soft constructivism underscoring the discursive nature of much of politics encourages historians to analyse past political discourses more systematically. Concepts such as nexus, historical body, mobility and discursive transfers borrowed from language research deepen our analytical understanding of the multi-level dynamics of policy-making, directing attention to links between various debates as well as to transnational transfers. Our empirical examples are derived from Swedish and Finnish constitutional debates in the last phase of the First World War, but similar research strategies are applicable to the analysis of political discourse in any context.

Keywords: methodology; political history; intellectual history; conceptual history; transnational history; history of political discourse; language policy research 


\section{A new perspective to political history}

Awareness of the linguistic and discursive nature of much of politics has been rising in fields of historical research such as intellectual history, the history of political thought and conceptual history since the 1960s. Conceptual history, for instance, focuses on what has been sayable and doable politically within past language, emphasising the political significance of layered meanings of contemporary conceptualisations rather than the study of mere 'reality', structures and institutions (Steinmetz and Freeden 2017, 2, 31). Just as in other human sciences, linguistic and discursive methodological turns have been followed by spatial, visual, material, transnational, mobility and digital turns. In more traditional political and social history, by contrast, emphasis in research has often remained on the material realities, actions or structures of policy-making as opposed to related social, cultural and discursive constructs. Even today, not all historians accept the notion that the use of language itself can be seen as action or that structures can be expressed and redefined linguistically (Marjanen 2018, 100). Yet the course of political discourse has often been more decisive for political attitudes and related physical actions than some simple state of 'facts'.

In this essay, we argue that a more systematic and outspoken use of linguistic and especially textual methodologies would benefit political history. Political history, after all, typically builds on textual data but without always explicating the textual methods it uses. While intellectual history, the history of political thought or conceptual history may be more explicit as to how they read and interpret texts, there is a tendency within them to recycle methodological principles introduced half a century ago, so some update might be welcome there as well. We believe that the approach we propose helps these different varieties of historical research to rethink their methodologies and to find common ground. We suggest that analyses of parliamentary discourse, for instance, can 
bring together traditional political history focused on actors, events and institutions on the one hand and language-oriented history of political discourse on the other. We argue, furthermore, that our transdisciplinary approach to the textual analysis of parliamentary politics may be applicable to the analysis of past and present political discourses in any forum of political debate.

Our suggested approach has been inspired by a soft version of social constructionism: we are not claiming that this world is nothing but socially construed discourse (also Müller 2014, 86, paraphrasing Reinhart Koselleck). We rather follow a critical realist point of view, where the materiality of social objects - whose meaning has been construed in social processes - and their discursive constructs are seen as dialogically intertwined. We acknowledge the existence of a physical reality independent of its discursive descriptions, but acknowledge that our knowledge of that reality is socially constructed (Scollon 2003, 78; Ifversen 2011, 67-68). We are aware of the limits of discourse analyses and interested in the implications of material realities and individual lived experiences for political discourse (Müller 2014, 76, 88). With linguistic textual analysis of politics at which we aim, we mean a linguistically and textually (see Blommaert 2005; Fairclough 1992) oriented discourse and policy analysis that pays attention to historical agency and continuities, material realities and the dialogical relationship between discourses and the actions and objects they describe. Our emphasis on time, space and the physical nature of discourses-as-action distinguishes our approach from general discourse analytical approaches which often lack historical sensitiveness (see Jokinen, Juhila and Suoninen 2016, for instance).

This suggested approach is by no means entirely new. Intellectual history inspired by Wittgensteinian language philosophy, historical pragmatics and historical semantics - has found an interest in how politics has been done with words and 
emphasised linguistic contextualism as the methodological point of departure (Skinner 2002). Continental varieties of language-oriented historical research have emerged mostly in the form of the history of concepts (Begriffsgeschichte) or conceptual history and the 'new' political history that emphasises the study of past human interaction and communication in which interlinked discourses are seen as central elements of political processes, institutions, events and action (Steinmetz 2002, 87; Steinmetz 2011, 4-5; Steinmetz 2013).

In order to demonstrate the novel features of our approach, we have selected the special field of parliamentary history. While debate has been recognised as a central characteristic of parliaments (the generic term being derived from parler), the dynamics of parliamentary discourse has seldom been subjected to detailed textual analyses. Historians have rather been interested in the formation, structures and practices of the representative institutions and parliamentary parties, in reconstructing parliamentary 'communication', in prosopographies or oral memories of parliamentarians, or in finding out how and why a parliament voted in a particular way and what the impact of such parliamentary action was. Under the influence of the cultural turn, more attention has been paid to political cultures constructed and expressed within representative institutions through regulations, practices, symbols, rituals, uses of space and performances, though not necessarily with a focus on the past use of language as political activity - at least not beyond rhetoric and oratory (Mergel 2002, Schulz and Wirsching 2012, Feuchter and Helmrath 2013, Weidner 2018, 40 for Germany; cf. Steinmetz 1993 and Burkhardt 2016; te Velde 2003, te Velde 2015 and Beyen and te Velde 2016 for the Low Countries; Roussellier 1997, Galembert, Rozenberg and Vigour 2014, Bouchet 2016 and Garrigues and Anceau 2016 for France). The analysis of language has been applied most often to British parliamentary debates (Skinner 1996; 
Steinmetz 2002; Ihalainen 2010; Peltonen 2013; Seaward and Ihalainen 2016). On the one hand, research on the norms of parliamentary debate has focused on possibilities for manoeuvre (Steinmetz 1993; Steinmetz 2002, 85-86; Toye 2014, 271, 297; te Velde 2015, 12, 14, 32-33; Palonen 2016b, 14). Discourse studies, on the other hand, has led to the analytical consideration of power relations shaped by parliamentary discourse (Ilie 2016). Textual analysis of parliamentary talk in which 'the political' emerges in dynamic human interaction in which the speakers react dialogically to each other's divergent arguments, has recently emerged also in the intersection of semiotics and political science (Turunen 2015, 21-22, 24).

In some recent analyses of parliamentary political theory and of political key concepts used in parliaments, the German tradition of historical semantics, the British tradition of the history of political thought and rhetorical analysis have been brought together (Palonen 2008; Ihalainen and Palonen 2009; Ihalainen 2010; Haapala 2012; Häkkinen 2014; Ihalainen 2014; Pekonen 2014; Kaarkoski 2016; Ihalainen, Ilie and Palonen 2016; Ihalainen 2017). While both macro and micro-level discourses and their interconnections may have been considered in such work, the dynamics of discourse and the roles that parliamentarians, political practices, physical objects (documents, podiums or meeting rooms) and psycho-physical experiences have not always become fully explicated and explained. Studies on connections between parliaments, the press and public debate more generally (Steinmetz 2002; Bösch 2012; te Velde 2015; Ihalainen 2013; Harvard 2016; Ihalainen and Matikainen 2016; Ihalainen 2017) have demonstrated the role of parliamentary debates in political discourse that has taken place in several interconnected forums. The international and transnational turns, furthermore, have directed attention to cultural transfers and to the political importance of transnational interaction side by side with nation states as sites for political struggles 
(see te Velde 2005, 206-208, and te Velde 2015, 20, for transnational parliamentary history, and Leonhard 2016, 162, for transnational interaction that involves changes in the objects of transfer; Müller 2014, 76). We aim at strengthening the consideration of all these potentially relevant aspects in future studies of parliamentary discourse.

The above-introduced approaches are entirely legitimate and in some respects related to what we suggest here. Yet by taking a more explicitly linguistic textual approach, it would become possible to explain the course of political processes and their diverse underlying dynamics in ways that might otherwise go unacknowledged. The approach makes us consider how not just political talk but physical political action is construed in a discursive setting and consequently how discourses and material forms of political action influence each other.

We suggest that parliaments and especially parliamentary debates can be seen as nexuses of societal power relations and ideologies expressed through the use of language side by side with other forms of physical action (see also Ihalainen, Ilie \& Palonen 2016). Our discussion consists of five parts: After having now briefly (i) summarised the state of the art in language-oriented political history especially from the point of view of parliamentary history, we next (ii) explain the analytical concepts we would like to add to the toolkit of political historians in order to facilitate methodological rethinking. We then proceed by (iii) introducing two empirical examples in their historical contexts and discuss them through the suggested concepts. This leads us to (iv) discuss the complexity of parliamentary debates as multi-sited intersections of discourse trajectories - that is nexuses, points of coming together, and finally to (v) conclude by suggesting directions for the study of parliamentary discourses as nexus where an increased awareness of textual strategies is needed. 


\section{Conceptualising discursive approaches for political history}

Discourse, which was originally used to refer to a particular communicative instance, has taken more societally extended meanings, referring to discourse as a form of knowledge, or as practices that constantly form the objects of which they speak (see Wodak 2001; Fairclough 2003; cf. Pocock 2009, 67). Michel Foucault's concept of discourse as deterministic, covering everything and dominating human action has been generally rejected by historians who rather emphasise the role of historical agents in forming discourses and meanings of concepts with intentions to change the state of affairs (Ifversen 2011, 75; Marjanen 2018, 100, 113).

While we find rhetorical approaches in the study of past politics interesting (see Finlayson 2007, 546, who suggests developing the analysis of the intersubjective persuasive processes of politics'), we distinguish between the analysis of parliamentary rhetoric and the textual analysis of the debates, a lot like Steinmetz and Freeden (2017, 28-9). For our textual analysis, we draw selected methodological tools from discourse analysis, including some elements of critical discourse analysis (see Fairclough 2003) and mediated discourse analysis (Scollon and Scollon 2004), rather than the conventionally used tools of classical and new rhetoric, or the more programmatic discourse-historical approach of Wodak (2015).

The empirical phenomenon of multi-sitedness of political discourses should be seen as a starting point in order to pay attention to the multi-layered and complex factors that are present in a particular political situation (Halonen, Ihalainen and Saarinen 2015). While the dialogical notion of discourse as both describing and construing action is theoretically widely accepted in socio-constructively oriented human sciences, the process of how 'discourse is action' - how policy discourses 
materialise in action and vice versa - remains empirically still unsolved, regardless of the theoretisations of policy as discursive and empirical analyses of discursive constructions of politics. A recent ethnographic turn in social sciences (see Blommaert and Rampton 2011; McCarty 2011; Scollon and Scollon 2004 for language ideologies and language policy) has proven to be useful in paying attention to the physical links between (micro) situations of language use and (macro) situations of societal processes. Discursive approaches that acknowledge the more networked or 'rhizomatic' (see Pietikäinen 2012) nature of policy-making have also helped to open what used to be blackbox of discourse as action. Recognising the multi-sitedness, i.e. the property of political discourses moving in time and space, in a number of potentially interconnected forums and layers simultaneously while being linked to past discourses and future expectations, leads to the analytical concepts which we wish to explain in what follows: nexus, historical body, space-time mobility and discursive transfers between different sites of political discourse.

As the concept of 'context' remains somewhat differently understood in historical research and language research we prefer to talk about nexus as a meeting points of different historical trajectories of discourses, people, action, practices, and material objects. The concept of nexus helps to understand the material nature of discourse, which is particularly topical in Ron Scollon's and Suzanne Wong Scollon's (2004) work. Nexus can be understood as an intersection of discourses in place (discourses taking place in some social occasion), interaction order (human behavior in interaction) and historical body (the lifelong experiences of the participants in the interaction). In understanding the nexus, of particular importance is the material nature of political contexts and historical continuities as they relate - often contingently or intentionally - to different actors and the events where the historical trajectories meet 
(see Scollon and Scollon 2004). The notion of discourse as mediated (i.e. mediated by various social and cultural tools that can be material or conceptual) is helpful here: discourse is specifically studied as physical human action as embodied and internalised in discursive transfers and physical practices.

Another helpful concept is that of the historical body, which focuses attention to the role of individuals as political agents, but also reminds of the simultaneity and reflexivity of all of their psycho-physical experiences and ongoing actions (Scollon and Scollon 2004; Halonen, Ihalainen and Saarinen 2015, 17). Focus on the historical body is not entirely unlike the contextualisation of political thought (social, cultural and political contexts, modes of writing, the corpus of the author, intentions, motives etc.) as understood in intellectual history by Dominick LaCapra (1983) or in the history of political thought by Quentin Skinner (2002). However, it differs from the mere biographical data in that it directs attention to the methodological implications of the spatial and material turns, emphasising the physical and embodied nature of discourses. Aware of the impossibility of conducting ethnographic research in a historical setting, we use the concept of nexus metaphorically rather than purely analytically. Nevertheless, a focus on a particular meeting point (or nexus) of the material and discursive trajectories helps us make methodological and empirical choices, as well as focus empirical analysis within the often overwhelming amount of historical textual data. For instance, the (verbal) debates and the (physical) political activities come together in a parliamentary situation as a nexus, where the different discourses and historical trajectories of people, ideas, actions, practices and discourses cyclically fuel each other. Because of this rhizomatic cyclicality, the notion of historical body gives us an analytical tool to overcome problematic micro-macro divisions. 
Several human sciences have recently been inspired by the spatial turn. The analysis of political discourse has been evolving from the linguistic, rhetorical and communicative analyses towards combining the aspects of time, space and movement. Combined with the ethnographic turn mentioned earlier, these methodological developments have had consequences for political history, calling for a closer consideration of spatialities in the study of political action. Parliamentary historians have previously discussed the significance of parliamentary space for political speaking (Steinmetz 2002, 87; Toye 2014, 277) but should perhaps adopt an even more holistic understanding of space, mobility and materiality in the lives of parliamentarians.

Related to the spatialities, our fields of research have also been affected by a mobility turn that has directed attention to transnational phenomena that have crossed national boundaries through interaction and cultural transfers. The previously introduced notion of multi-sitedness is derived from the spatial turn and awareness of the existence of trajectories between various forums of political debate in one country as well as transnational links between polities and their representative institutions. Comparative and transnational debates have occurred in several parliaments nearly simultaneously, interconnected by the historical bodies of parliamentarians and the embodiments of their education, academic backgrounds, internationalist ideologies, media etc. It is helpful to view complex historical cases of multi-sited and mobile political debates through a methodological lens that focuses on nexuses where historical trajectories meet, creating new trajectories.

The nexus analytical concept of historical body can add to our understanding of the mechanisms of not just vertical (micro - macro) but also horizontal transfers between political cultures. Individuals play key roles in rhizomatically linked national policy debates, transnational interaction and connected mobility. By rhizomatic links, 
we mean the ways in which discourses connect and cluster (see Pietikäinen 2012). Past political actors with their multiple and overlapping roles have often constituted concrete connections between multi-sited discourses, conveyed transfers from one political culture to another (te Velde 2005, 208, on the role of individuals and the media in migrations) and between different forums in a single political culture.

We will next move on to examine two empirical cases, the parliamentarians Hjalmar Branting in Sweden and Evert Huttunen in Finland, by applying the concepts discussed earlier.

\section{Two nexuses from Sweden and Finland in the revolutionary 1917}

In the following two empirical examples, we focus on the individual parliamentarians with the purpose to demonstrate what paying attention to the physical mobility of historical bodies in space and the connected discursive transfers in a nexus of parliamentary debate means for the textual analysis of parliamentary discourse. We thereby also demonstrate the significance of the phenomenon of multi-sitedness. Our examples originate from Sweden and Finland in 1917. The war, connected revolutions, suffrage reforms, declarations of independence and new constitutions then led to redefinitions of political participation. The concepts of the people, democracy and parliamentarism were given new meanings as transnationally connected competing ideologies confronted each other in parliamentary debates as nexuses (Ihalainen 2017).

Our first instance comes from Sweden and April 1917, a month after the outbreak of the Russian Revolution. Bolshevik leader V.I. Lenin and thirty other Russian radical socialists had left Switzerland on 9 April 1917 and were on the move by train through Germany, Sweden and Finland towards Petrograd. They crossed Sweden 
on 13-14 April and were hosted by radical Leftist MPs on their way. Hjalmar Branting, an internationally well-connected Swedish revisionist social democratic leader, was simultaneously returning from Petrograd, which he had visited to create links to the leaders of the Revolution, some of whom he knew from his youth. He had countered diversified revolutionary discourses in Petrograd, met some radicalized Finnish socialists in Helsinki, given interviews to the press on his experiences and drafted a parliamentary speech during his train journey through Finland and Northern Sweden. Back in Stockholm, he directly entered a debate in parliament in which the postponed question of extending suffrage was once again on the agenda. In the debate, he made use of the frescos of the chamber (in the planning of which he had participated a few years previously) to reinforce his narrative on a thousand years of democracy and parliamentarism in Sweden (Ihalainen 2015). Mobility through space, a time trajectory spanning this journey, and the political use of parliamentary space came together in his speech in the nexus of a parliamentary debate, with Branting's historical body providing the links between macro and micro spaces during this time.

Branting's role in this cross-national space, crossing boundaries, contributing to transnational discursive transfers, and reinforcing historical trajectories becomes clear in his contribution to the ongoing debate in Sweden. At the time, hunger demonstrations and open extra-parliamentary agitation hinted to a possible extension of the revolution to Sweden, as the country suffered from serious wartime shortages. In a press interview which he had given immediately after having crossed the border from Finland (the Russian Empire) to Sweden, Branting had stated that the Russian Revolution had started "an entirely new era" (Social-Demokraten, 13 April 1917). In parliament, he used an intertextual reference, linking his speech to the French revolutionary tradition by addressing the members with the term 'citizens', which made the anti-reformist Right 
laugh at what they saw as excessive enthusiasm for the events in Russia (Palmstierna 1953; AK, 14 April 1917, 46; Social-Demokraten, 16 April 1917). Branting painted images of an ongoing global revolution: the world had seen "the greatest events since the time of the French Revolution" as Russia was turning into a democratic republic. A suffrage reform in Prussia, which had been discussed at the Reichstag in Berlin two weeks previously and which the Kaiser had indirectly promised a week earlier, would be even more decisive for Sweden.

According to Branting, the signs of the time forced the Swedish people to look for more powerful means to push through a suffrage reform despite constant rightist opposition (AK, 14 April 1917, 41:63-4, 66). While those calling for "a democratic order" had customarily looked at "Western democracies" and Sweden's smaller neighbours taking steps towards democracy, Branting concluded that now even Russia and Prussia would pass Sweden in democracy (AK, 14 April 1917, 41:66-7). Even if to some extent inspired by revolutionary enthusiasm transmitted from Petrograd, Branting had written a conspicuously moderate speech to force through a domestic reform. His conclusion on the Russian Revolution (and on the Finnish sister party as well) had been that it did not provide a model the Swedish socialists, who rather prioritized parliamentary cooperation.

In his speech, however, Branting did not exclude the possibility of revolutionary action at home. Social-Demokraten saw the rejection of the reform by the Swedish right as "a stroke on the face of the Swedish people" and echoed the suggestion that "the battle must now be fought by other means" (Social-Demokraten, 16 April 1917). Two forums of political debate in the possession of a party were employed to reinforce the message. The leaders of the far left, who had on the preceding two days accompanied Lenin, were likewise enthusiastic about an ongoing revolution that would remould the 
world. They congratulated Branting and the Swedish people - somewhat ironically towards the revisionist social democrats - for his having brought revolutionary breezes from Petrograd and urged the parties of the left to prepare for a concrete "constitutional battle" instead of a mere battle of the words (Carl Lindhagen, AK, 14 April 1917, 41:71; Fredrik Ström, FK, 14 April 1917, 32:17; Dagens Nyheter, 14 April 1917). The last one was a typical discursive operationalization, i.e. a discursive construction of a desired course of action, suggesting that ineffective parliamentary debate was to be replaced with procedural, extra-parliamentary and potentially revolutionary violent action. A rightist leader, on the other hand, complained about leftist leaders running as heralds between Petrograd and Stockholm and abusing threats of a revolution that would not persuade the Swedish people who had no reason for discontent (Ernst Lindblad, FK, 14 April 1917, 32:24). It thus seems that both sides were drawing their arguments from a time-space trajectory that spanned across several countries and cycled different, even competing discourses.

The debaters in this nexus were highly aware of cross-border mobility as a source of international comparisons and potential transnational transfers that might open new political visions for the future at the national level. Branting embodied (both socially and personally or idiosyncratically) life experiences from party and revolutionary trajectories, internalized in his historical body. These were moulded by his physical and mental experiences, combined with historical trajectories in Swedish and European history and the current events in Russia and Germany, and supporting the domestic reform policies of his party. Transnational transfers surrounding the revolution as they can be observed here by no means determined the course of the reform process in Sweden but they evidently affected the course of the connected discursive process, giving it a new direction. Considering the mental and physical experiences of 
parliamentarians as historical bodies moving in various spaces, their role as links between various forums of debate evidently deserve attention in the analysis of the dynamics of discourse and hence political processes.

The implications of multi-sitedness and parliamentary debates as nexuses and the potential significance of transnational discursive transfers can also be illustrated with an example from Finland and the revolutionary summer of 1917, a part of a political process that would end up with 'the Finnish Revolution' and a civil war in 1918. We will hence move to analyse the revolutionary nexus through the historical body of Evert Huttunen, an Ingrian journalist and social democratic politician who was able to move between Finnish and Russian political circles during the revolution. Finnish social democrats were then debating on the streets, in the press, local associations, trade unions, the Red Guards, meetings with radicalized Russian soldiers in Helsinki, revolutionary assemblies in Petrograd, the so-called 'parliament' of the Helsinki labour, an all-party government, and the national parliament. Such multisitedness, close links to revolutionary Russians and the closure of connections to Western European social democratic debates explain much of their exclusive uses of the concepts of 'the people', 'democracy', 'parliamentarism' and 'revolution' in the rising political confrontations within Finland in the aftermath of the fall of the Romanov dynasty. The local situation in Helsinki was influenced by transnational transfers from Russia and affected for its part the course of discourse throughout Finland. These transnational transfers added to existing radicalization in Finnish socialist discourse and eventually contributed - as a further element - to the outbreak of a civil war in January 1918 (Ihalainen 2017).

After the outbreak of the Russian Revolution in mid-March 1917, double authorities rose in Finnish towns, just as they had in Petrograd. The Parliament 
(Eduskunta) of the Labour Associations of Helsinki was formed to challenge city administration and with its name also the authority of the national parliament. 'The parliament of the streets' was also rising: not only the press, but also the city space provided political groups with possibilities to search for common stands, propagate views and demonstrate strength in order to put pressure on decision-makers. The national parliament itself convened in the midst of this turbulent city space, debating at times in a state of siege so that shouts against bourgeoisie from the street could be heard in the assembly hall (Nyström 2013, 125-6, 131, 135, 139, 151). This rise of revolutionary atmosphere was supported by concrete transnational links between Petrograd and Helsinki such as train connections, the presence of politically radicalized Russian troops, and Russian revolutionary leaders hiding in Helsinki (Dubrovskaia 2015).

The Finnish labour movement had employed radical revolutionary rhetoric already during the election campaign of 1916 which had produced a social democratic parliamentary majority. The Russian Revolution and the rise of Bolshevik opposition in Russia - supportive of the constitutional demands of the Finnish social democrats as a way to extend the Revolution to the west - opened them prospects for the realization of longed for reforms. Inspiring Finnish-speaking emissaries of the revolution were sent to Helsinki. Social democratic parliamentarians tended to become dependent on revolutionary discourse imported from Petrograd and the changing opinions of the streets (Nyström 2013, 137-8). Inspired by the models, their parliamentary discourse turned increasingly confrontational, emphasizing inevitable contrasts between the educated classes and the people proper (the proletariat) as the democracy and the necessity of a revolution and civil war to destroy capitalist society. They demanded, with support gained from the Russian Congress of Soviets, that all political power 
should be transferred to the Finnish parliament as the only legitimate representative of the power of the people (Ihalainen 2017).

Evert Huttunen, fluent in Russian, acted as a transnational link between revolutionary assemblies in Petrograd and Finnish political debate. Back in the Finnish parliament after a trip to the Russian Congress of Soviets, Huttunen advocated the exclusive social democratic definition of democracy, arguing that "the revolutionary democracy of Russia" supported "the campaign of the Finnish democracy" and had invited "the Finnish democracy and especially social democracy to join its forces with the Russian democracy to ensure the victory of the Russian Revolution" (VP, 10 July 1917, 900-1, 904).

Long-lasting domestic agitation, transnational connections to Bolshevik discourse, weak links to Western revisionist social democracy and a socialist parliamentary majority made the Finnish social democratic concepts of the people, democracy, parliamentarism and revolution exceptionally exclusive and divisive. The cause of democracy became defined in the Finnish social democratic discourse as identical with the cause of the party itself and even with the Bolshevik version of the Russian Revolution, which excluded the non-socialist parties from cooperation. This definition of democracy, reminding radical Russian revolutionary discourse, distanced the Finnish socialist discourse further from German and Swedish revisionism that welcomed cooperation with bourgeois reformists and removed possibilities for a consensual discourse on democracy in Finland (Ihalainen 2017).

Through such uncompromising and universalist conceptualizations and accusations that the Finnish bourgeoisie were all counter-revolutionaries, the policy line of the social democrats became associated by the Finnish non-socialist parties with the Bolshevik revolutionaries. The radical Bolshevik version of revolutionary discourse 
tended to take over the discourse of the Finnish social democratic parliamentary majority, defining it as "the legal representative of the workers of the Finnish people" in a potentially revolutionary sense (E. Huttunen, VP, 10 July 1917, 901), even if many in the party, including Huttunen himself, would later oppose the introduction of the dictatorship of the proletariat through a revolution (Ihalainen 2019). Similar discursive transfers appeared in even more radicalized ways in the Finnish parliament after the Bolshevik Revolution in Russia (Ihalainen 2017).

\section{Complex historical debates as multi-sited}

In the above examples, Branting, Huttunen and their fellow MPs were engaged in a debate on a revolution moulded by speech acts carried out by agents with diverse embodied long- and short-term experiences and ideologically motivated understandings of political reality. A temporally and spatially multi-sited approach makes these layered policy discourses visible, as they take place, are constructed, contested and reproduced rhizomatically on different horizontal and vertical levels. Focus on a historical body such as Branting or Huttunen, moving in a trajectory that links these points, helps us better see the materialities of these basically discursive encounters. The temporality of these trajectories becomes apparent as a variety of policy actors make references to the past and reinforce and potentially recycle political discourses in interaction with each other and the political process.

Multi-sitedness thus not only implies a local or temporal emergence of discourses - made physical as debates in the academia, civil society, the media and parliaments nationally and internationally - but also the coming together of these trajectories which then merge in a nexus at some space and time, potentially giving rise 
to new discourses (Halonen, Ihalainen and Saarinen 2015, 3, 17). The notion of nexus (Scollon and Scollon 2004) is thus applicable not only as an extension of the concept of intertextuality but as a fundamental extension of discourse as essentially material rather than 'merely' textual.

Multi-sitedness involves the recognition of a variety of forums within a national debate and transnationally, with extra-parliamentary public, academic or private debates and their interconnectedness being taken into account. The preceding examples suggest that parliamentary politics are interconnected with a multi-sited political discourse locally, nationally and potentially transnationally so that the mobility, experiences and actions of historical bodies (together with media debates as an alternative route) constitute key links. The focus of analysis in political history could hence move towards the analysis of process-like, mobile and rhizomatically linked political discourses and the consideration of the effects of the multi-sitedness on past politics. In the case of Branting, for example, the parliamentary debate he participated in after returning to Sweden did not need to be a particularly consequential debate as such; the complex trajectories and his embodied experiences meeting in a debate nexus would be equally interesting to study in another situation. However, what is interesting is to observe any nexus as an assemblage of the different discursive and material layers that meet in it, and to analyse the emerging interpretations of any one parliamentary debate or event. This implies consideration of interaction within and between political parties and the related mobility of discourses at various levels, including historical trajectories, links to other national and international debates, cross-national transfers and references to the future.

Past politicians have typically participated in a variety of discursive processes through their mobility and the ensuing active use of language. The notion of the multi- 
sitedness of intersecting past and contemporary political discourses may seem to expand the number and complexity of contexts. In the case of Huttunen, described above, his layered experiences, personal properties, origins and travels may seem overwhelming when studied as a combination of long term personal and political historical contexts. Yet, we suggest that analytical attention to trajectories and nexuses that are related to a person, text, theme or concept, for instance, helps to focus research, directing analytical attention to the actions of politicians as language users on various forums and the nexuses in which their movement in time and space meet. Even if the focus may remain on parliamentary debate as political activity, we need to be aware of numerous other contemporary discourse trajectories that are potentially interlinked to other parliamentary debates and historical events.

\section{Directions for the study of parliamentary discourses as nexus}

We have argued that political history and particularly the history of political discourse should be open to impulses from language policy research. Such methodological crossfertilisation would imply more systematic emphasis on the meaning of spatiality, mobility and multi-sitedness in politics and potentially the application of the analytical categories of nexus, historical body, mobility in space and discursive transfer. We have demonstrated the helpfulness of interpreting parliamentary debates as active participations in discursive processes of policy construction. They are then seen as a central form of ongoing temporal and spatial discursive processes in the sense of being interlinked to past and contemporary discourses in other contexts through historical trajectories and by historical bodies and their mobility. 
A situated parliamentary debate can be interpreted in a focused way as a nexus of historically layered, multi-sited and often nationally and transnationally interconnected policy discourses. In a debate, different ideological, national, international and transnational trajectories of historical and present-day discourses and continuities which they represent can meet in a material historical context, affecting and even creating the dynamics of the debate. Particular attention should hence be paid to links to other past and parallel national and international forums of multi-sited debate. This combination or downright clash of diverse discourses in a political nexus can give rise to entirely new discourses applicable to changing political circumstances, or revive old confrontations, and potentially affect the physical outcomes.

The metaphorical notion of a parliamentary or any political debate as a nexus enables us to use a more limited corpus instead of exploring huge empirical data, just as the focus on trajectories helps to specify what exactly should be seen as relevant among historical contexts. The notion of multi-sitedness, with focus on nexuses and trajectories, works well in source-based research on past politics, raising awareness of the discursive dynamics of parliamentary debates and their interconnectedness with various extra-parliamentary and potentially transnational debates.

The gap between 'political history' studying institutions, events and action on the one hand and 'intellectual history' or 'conceptual history' studying thought and debate on the other can be bridged once we understand past politics essentially (though by no means merely) as discursive. Discursive tensions are then seen as reflective of competing understandings of politics and struggles for power (Halonen, Ihalainen and Saarinen 2015, 14; Ihalainen and Saarinen 2015, 33; Ilie 2016, 134), and even institutions can be seen as conceptually redefinable (Ifversen 2011, 83). 
Discourses form cycles that appear and reappear in parliamentary debates, surfacing in different times and places. These discourse cycles may meet in a particular nexus, where the historical trajectories and embodied life experiences of the historical bodies meet. These historical bodies have not only been moulded by differing physical or material experiences such as worsening economic conditions, the presence of radicalised crowds in the city, or the possibility to take a train to the centre of revolution to experience it and to participate in it. These actors - the historical bodies simultaneously mould those same processes while interpreting them to serve one's political interests at home.

Side by side with the analysis of the causes and consequences of past events that has been typical of political history, we should also analyse multi-sited discursive processes that have given rise to differing views on policy questions and contributed, sometimes decisively, to the rise and course of historical events. We should hence consider the dynamics of political debate side by side with social and economic structures or the activities of individual politicians when explaining political events. It seems that the intertwining of physical realities with mental interpretations of them have directed the course of political processes. Ways of speaking can turn into ways of thinking and finally to ways of acting.

Historical and language research could learn from each other by trying to better understand the nuances of the text (as far as historians are concerned) and by trying to better understand the nuances of time (as far as discourse analysts are concerned). We also remain aware of the diverse perspectives of various genres of historical and language research. What works in the analysis of parliamentary discourse may not be directly applicable to other sources. Yet almost any source in political history can be 
seen as a contribution to discourse and hence potentially subject to research strategies similar to those in the history of political discourse as described here.

We see methodologically conscious analyses of discursive politics as providing not just alternative or complementary but also causal explanations to contingent political processes in the past. Such analyses can increase our awareness of the fundamental interconnectedness of action and discourse in politics - be that political history, history of political discourse, history of any field of human activity, or the analysis of present day politics from the point of view of language policies or political theory. They would, indeed, address the key issue of science trying to understand both the material conditions of human lives and social constructions of reality made by humans as well as the methodologically complex interrelation between the two.

\section{Disclosure statement}

The authors reports no financial interests or potential conflicts of interest.

\section{Notes on contributors}

Dr Pasi Ihalainen is Professor of Comparative European History at the Department of History and Ethnology, University of Jyväskylä, Finland. He has published widely on the secularisation of political discourse, the discursive construction of national identities, the conceptual history of democracy, and parliamentary and constitutional history since the 18th century, applying comparative and transnational perspectives. He has cooperated with political theorists and language policy researchers to develop methods for the empirical study of the history of political discourse. His recent books 
include Parliament and Parliamentarism: A Comparative History of a European Concept, co-edited with Cornelia Ilie and Kari Palonen (Berghahn, 2016), and The Springs of Democracy: National and Transnational Debates on Constitutional Reform in the British, German, Swedish and Finnish Parliaments, 1917-1919 (Finnish Literature Society, 2017).

Dr Taina Saarinen specialises in applied language studies at the University of Jyväskylä, Finland, where she is currently working as Senior Researcher and Head of the Centre for Applied Language Studies. She is particularly interested in 'discursive operationalisation' of policy (specifically on language education) and currently works on the theoretical conceptualisation of policy as multi-sited and material. Her recent articles deal with the use of textual methodologies in higher education policy studies, the conceptualisation of policy change, and the invisibility of language in Finnish internationalisation policies for higher education. Her research curiosity is mostly sparkled by multidisciplinary research settings, which often make visible new issues and unobserved gaps in existing research. ORCiD 0000-0002-5117-2756.

\section{References}

Beyen, Marnix, and Henk te Velde. 2016. "Passion and Reason: Modern Parliaments in the Low Countries." In Parliament and Parliamentarism: A Comparative History of a European Concept, edited by Pasi Ihalainen, Cornelia Ilie, and Kari Palonen, 81-96. New York: Berghahn.

Blommaert, Jan. 2005. Discourse: A Critical Introduction. Cambridge: Cambridge University Press. 
Blommaert, Jan, and Ben Rampton. 2011. "Language and Superdiversity." Diversities $13(2), 1-22$.

Bösch, Frank. 2012. "Parlamente und Medien. Deutschland und Grossbritannien seit dem späten 19. Jahrhundert." In Parlamentarische Kulturen in Europa: Das Parlament als Kommunikationsraum, edited by Andreas Schulz and Andreas Wirsching, 371-88. Düsseldorf: Dorste Verlag.

Bouchet, Thomas. 2016. "French Parliamentary Discourse, 1789-1914." In Parliament and Parliamentarism: A Comparative History of a European Concept, edited by Pasi Ihalainen, Cornelia Ilie and, Kari Palonen, 162-75. New York: Berghahn.

Burkhardt, Armin. 2016. "German Parliamentary Discourse since 1848 from a Linguistic Point of View." In Parliament and Parliamentarism: A Comparative History of a European Concept, edited by Pasi Ihalainen, Cornelia Ilie, and Kari Palonen, 17691. New York: Berghahn.

Dagens Nyheter. 1917.

Dubrovskaia, Elena. 2015. "The Russian Military in Finland and the Russian Revolution". In Russia's Home Front in War and Revolution, 1914-22. Book 1: Russia's Revolution in Regional Perspective, edited by Sarah Badcock, Liudmila G. Novikova, and Aaron B. Retish. Bloomington: Slavica Publishers.

Fairclough, Norman. 1992. Discourse and Social Change. Cambridge: Wiley. Fairclough, Norman. 2003. Analysing Discourse: Textual Analysis for Social Research. London: Routledge.

Feuchter, Jörg, and Johannes Helmrath. 2013. Parlamentarische Kulturen vom Mittelalter bis in die Moderne: Reden - Räume - Bilder. Düsseldorf: Droste Verlag. 
Finlayson, Alan. 2007. "From Beliefs to Arguments: Interpretative Methodology and Rhetorical Political Analysis." British Journal of Politics and International Relations, 9 (4), 545-63.

Galembert, Claire de, Olivier Rozenberg, and Cécile Vigour (eds). 2014. Faire parler le Parlement. Méthodes et enjeux de l'analyse des débats parlementaires pour les sciences sociales. Paris: L.G.D.J.

Garrigues, Jean and Eric Anceau. 2016. "Discussing the First Age of French Parliamentarism (1789-1914)." In Parliament and Parliamentarism: A Comparative History of a European Concept, edited by Pasi Ihalainen, Cornelia Ilie, and Kari Palonen, 49-61. New York: Berghahn.

Haapala, Taru. 2012. "That in the opinion of this House”: The parliamentary culture of debate in the nineteenth-century Cambridge and Oxford Union Societies. Jyväskylä: University of Jyväskylä. http://urn.fi/URN:ISBN:978-951-39-4970-9

Häkkinen, Teemu. 2014. The Royal Prerogative redefined: Parliamentary debate on the role of the British Parliament in large-scale military deployments, 1982-2003. Jyväskylä: University of Jyväskylä. http://urn.fi/URN:ISBN:978-951-39-5592-2 Halonen, Mia, Pasi Ihalainen, and Taina Saarinen. 2015. "Diverse discourses in time and space: Historical, discourse analytical and ethnographic approaches to multi-sited language policy discourse." In Language Policies in Finland and Sweden. Interdisciplinary and Multi-Sited Comparisons, edited by Mia Halonen, Pasi Ihalainen, and Taina Saarinen, 3-26. Bristol, Multilingual Matters.

Harvard, Jonas. 2016. “War and 'World Opinion': Parliamentary Speaking and the Falklands War.” Parliamentary History 35 (1), 42-53.

Ifversen, Jan. 2011. "About Key Concepts and How to Study Them." Contributions to the History of Concepts 6 (1), 65-88. 
Ihalainen, Pasi. 2010. Agents of the People: Democracy and Popular Sovereignty in British and Swedish Parliamentary and Public Debates, 1734-1800. Leiden: Brill.

Ihalainen, Pasi. 2013. "Parlamentsdebatten und der Aufstieg außerparlamentarischer Medien im späten 18. Jahrhundert. Schweden, Großbritannien und die Niederlande. In Parlamentarische Kulturen vom Mittelalter bis in die Moderne: Reden - Räume Bilder, edited by Jörg Feuchter and Johannes Helmrath, 97-113. Düsseldorf: Droste Verlag.

Ihalainen, Pasi. 2014. "Prospects for Parliamentary Government in an Era of War and Revolution: Britain and Germany in Spring 1917." In The Politics of Dissensus: Parliament in Debate, edited by Kari Palonen, Jóse María Rosales, and Tapani Turkka, 423-448. Santander: Cantabria University Press \& McGraw-Hill.

Ihalainen, Pasi. 2015. "The $18^{\text {th }}$-Century Traditions of Representation in a New Age of Revolution: History Politics in the Swedish and Finnish Parliaments, 1917-1919." Scandinavian Journal of History 40 (1), 70-96.

Ihalainen, Pasi. 2017. The Springs of Democracy: National and Transnational Debates on Constitutional Reform in the British, German, Swedish and Finnish Parliaments, 1917-1919. Helsinki: Finnish Literature Society. https://doi.org/10.21435/sfh.24.

Ihalainen, Pasi, Cornelia Ilie, and Kari Palonen. 2016. "Parliament as a Conceptual Nexus." In Parliament and Parliamentarism: A Comparative History of a European Concept, edited by Pasi Ihalainen, Cornelia Ilie, and Kari Palonen, 1-16. New York: Berghahn.

Ihalainen, Pasi, and Satu Matikainen. 2016. "The British Parliament and Foreign Policy in the Twentieth Century: Towards Increasing Parliamentarisation?" Parliamentary History 35 (1), 1-14. 
Ihalainen, Pasi, and Kari Palonen. 2009. "Parliamentary sources in the comparative study of conceptual history: methodological aspects and illustrations of a research proposal." Parliaments, Estates and Representation 29 (1), 17-34.

Ihalainen, Pasi, and Taina Saarinen. 2015. "Constructing 'Language' in Language Policy Discourse: Finnish and Swedish Legislative Processes in the 2000s". In Language Policies in Finland and Sweden. Interdisciplinary and Multi-Sited Comparisons, edited by Mia Halonen, Pasi Ihalainen, and Taina Saarinen, 29-56. Bristol: Multilingual Matters.

Ilie, Cornelia. 2016. "Parliamentary Discourse and Deliberative Rhetoric." In Parliament and Parliamentarism: A Comparative History of a European Concept, edited by Pasi Ihalainen, Cornelia Ilie, and Kari Palonen, 133-45. New York: Berghahn. Jokinen, Arja, Kirsi Juhila, and Eero Suoninen. Diskurssianalyysi. Teoriat, peruskäsitteet ja käyttö. Tampere: Vastapaino.

Kaarkoski, Miina. 2016. 'Energiemix' versus 'Energiewende': Competing conceptualisations of nuclear energy policy in the German parliamentary debates of 1991-2001. Jyväskylä: University of Jyväskylä. http://urn.fi/URN:ISBN:978-951-39-

\section{$\underline{6738-3}$}

LaCapra, Dominick. 1983. Rethinking Intellectual History: Texts, Contexts, Language. New York: Cornell University Press.

Leonhard, Jörn. 2016. “Comparison, Transfer and Entanglement, or: How to Write Modern European History today?” Journal of Modern European History 16 (2), 14963.

Marjanen, Jani. 2018. “Begreppshistoria.” In Metod. Guide för historiska studier, edited by Martin Gustavsson and Yvonne Svanström, 97-132. Lund: Studentlitteratur. McCarty, Teresa. 2011. Ethnography and Language Policy. New York: Routledge. 
Mergel, Thomas. 2002. Parlamentarische Kultur in der Weimarer Republik. Politische Kommunikation, symbolische Politik und Öffentlichkeit im Reichstag. Düsseldorf: Droste Verlag.

Müller, Jan-Werner. 2014. "On Conceptual History.” In Rethinking Modern European Intellectual History, edited by Darrin M. McMahon and Samuel Moyn, 74-93. Oxford: Oxford University Press.

Nyström, Samu. 2013. Helsinki 1914-1918. Toivon, pelon ja sekasorron vuodet. Helsinki: Minerva.

Palmstierna, Erik. 1953. Orostid. Politiska dagboksanteckningar, vol. 2: 1917-1919. Stockholm: Tiden.

Palonen, Kari. 2008. The Politics of Limited Times: The Rhetoric of Temporal Judgment in Parliamentary Democracies. Baden-Baden: Nomos.

Palonen, Kari. 2016a. "Thinking of Politics in a Parliamentary Manner: Perspectives on the Conceptual History of Parliamentarism." In Parliament and Parliamentarism: A Comparative History of a European Concept, edited by Pasi Ihalainen, Cornelia Ilie, and Kari Palonen, 228-42. New York: Berghahn.

Palonen, Kari. 2016b. From Oratory to Debate: Parliamentarisation of Deliberative Rhetoric in Westminster. Baden-Baden: Nomos.

Palonen, Kari, Jóse María Rosales, and Tapani Turkka. 2014. “Introduction: The Parliamentary Politics of Dissensus." In The Politics of Dissensus: Parliament in Debate, edited by Kari Palonen, Jóse María Rosales, and Tapani Turkka, 1-19. Santander: Cantabria University Press \& McGraw-Hill.

Pekonen, Onni. 2014. Debating "the ABCs of parliamentary life": the learning of parliamentary rules and practices in the late nineteenth-century Finnish Diet and the 
early Eduskunta. Jyväskylä: University of Jyväskylä. http://urn.fi/URN:ISBN:978-951$\underline{39-5843-5}$

Peltonen, Markku. 2013. Rhetoric, Politics and Popularity in Pre-Revolutionary England. Cambridge: Cambridge University Press.

Pietikäinen, Sari. 2012. "Kieli-ideologiat arjessa. Neksusanalyysi monikielisen inarinsaamenpuhujan kielielämäkerrasta." Virittäjä 116 (3), 410-40.

Pocock, John G.A. 2009. Political Thought and History: Essays on Theory and Method. Cambridge: Cambridge University Press.

Riksdagens protokoll vid ... riksmötet .... Andra kammaren (AK) [Proceedings of the Swedish Parliament, Second Chamber]. 1867-1948. Stockholm: Riksdagen.

Riksdagens protokoll vid ... riksmötet .... Första kammaren (FK) [Proceedings of the Swedish Parliament, First Chamber]. 1867-1948. Stockholm: Riksdagen. Roussellier, Nicolas. 1997. Le parlement de l'éloquence: la souveraineté de la déliberation au lendemain de la Grande Guerre. Paris: Presses de Sciences Po. Saarinen, Taina, and Pasi Ihalainen. 2018. "Multi-sited and Historically Layered Language Policy Construction: Discourse cycles on constitutional bilingualism in parliamentary debate on the Finnish 1919 constitution.” Language Policy 17 (4): 54565.

Schulz, Andreas, and Andreas Wirsching (eds). 2012. Parlamentarische Kulturen in Europa: Das Parlament als Kommunikationsraum. Düsseldorf: Droste Verlag.

Scollon, Ron. 2003. "The Dialogist in a Positivist World: Theory in the Social Sciences and the Humanities at the End of the Twentieth Century." Social Semiotics 13 (1), 7188.

Scollon, Ron, and Suzanne Wong Scollon. 2004. Nexus Analysis: Discourse and the Emerging Internet. London and New York: Routledge. 
Seaward, Paul, and Pasi Ihalainen. 2016. "Key Concepts for Parliament in Britain (1640-1800)." In Parliament and Parliamentarism: A Comparative History of a European Concept, edited by Pasi Ihalainen, Cornelia Ilie, and Kari Palonen, 32-48. New York: Berghahn.

Skinner, Quentin. 1996. Reason and Rhetoric in the Philosophy of Hobbes. Cambridge: Cambridge University Press.

Skinner, Quentin. 2002. Visions of Politics, Volume I: Regarding Method. Cambridge: Cambridge University Press.

Social-Demokraten 1917.

Steinmetz, Willibald. 1993. Das Sagbare und das Machbare. Zum Wandel politischer Handlungsspielräume - England 1789-1867. Stuttgart: Klett-Cotta.

Steinmetz, Willibald. 2002. Begegnungen vor Gericht. Eine Sozial- und Kulturgeschichte des englischen Arbeitsrechts 1850-1925. Munich: Oldenbourg Verlag. Steinmetz, Willibald. 2011. Political Languages in the Age of Extremes. London: German Historical Institute.

Steinmetz, Willibald, Ingrid Gilcher-Holtey, and Heinz-Gerhard Haupt (eds). 2013. Writing Political History Today. Frankfurt: Campus Verlag.

Steinmetz, Willibald, and Michael Freeden. 2017. "Introduction: Conceptual History: Challenges, Conundrums, Complexities." In Conceptual History in the European Space, edited by Willibald Steinmetz, Michael Freeden, and Javier Fernández-Sebastián, 1-46. Oxford \& New York: Berghahn.

Toye, Richard. 2014. "The Rhetorical Culture of the House of Commons after 1918." History 99 (4), 270-98.

Turunen, Jaakko. 2015. Semiotics of Politics: Dialogicality of Parliamentary Talk. Uppsala: Uppsala universitet. 
Valtiopäiväasiakirjat (VP), Pöytäkirjat [Proceedings of the Finnish Parliament]. 19071975. Helsinki: Eduskunta.

Velde, Henk te. 2003. Het theater van de politiek. Amsterdam: Wereldbibliotheek.

Velde, Henk te. 2005. "Political Transfer: An Introduction." European Review of History: Revue européenne d'histoire 12 (2), 205-21.

Velde, Henk te. 2015. Sprekende politiek: redenaars en hun publiek in de parlementaire gouden eeuw. Amsterdam: Bert Bakker.

Wodak, Ruth. 2001. "What CDA is about - a summary of its history, important concepts and its developments." In Methods of Critical Discourse Analysis, edited by Ruth Wodak and Michael Meyer, 1-14. London: SAGE Publishing.

Wodak, Ruth. 2015. “Critical Discourse Analysis, Discourse Historical Approach.” In The International Encyclopedia of Language and Interaction, edited by Karen Tracy, Cornelia Ilie, and Todd Sandel, 275-88. Chichester: Wiley-Blackwell. 